\title{
What's Language Got to do with it? An Exploration into the Learning Environment of Quebec's Classes d'Accueil
}

\author{
Gabrielle Breton-Carbonneau (Concordia University) \\ Ailie Cleghorn (Concordia University)
}

\begin{abstract}
This article stems from an on-going qualitative study of the 'environment' of Montreal's elementary level welcome classes for new immigrant students (classes d'accueil), including teachers' language attitudes and actual language practices in the classroom. Since the official language of instruction in Quebec is French, the classe d'accueil provides a unique setting for exploring many issues: how teachers look upon the linguistic and cultural diversity of their learners; how teachers negotiate their way between potentially opposing tensions-- to integrate newly arrived children into Quebec, and, to reinforce Quebec's distinct cultural and linguistic status. By drawing on socio-cultural theory of language learning, this study explores the manner in which teachers might foster an inclusive learning environment in the classe d'accueil.
\end{abstract}

\begin{abstract}
Résumé
Cet article est le résultat d'une étude qualitative en cours à l'école primaire qui analyse l'environnement des classes d'accueil pour nouveaux immigrants à Montréal. Elle analyse également les attitudes linguistiques et les pratiques langagières des professeurs dans la salle de classe. Comme la langue officielle de l'éducation au Québec est le français, ces classes d'accueil offrent un environnement unique pour explorer beaucoup de questions : comment les professeurs perçoivent-ils la diversité culturelle et linguistique de leurs apprenants, comment négocient-ils les tensions opposées, c'est-à dire comment font-ils pour intégrer des enfants qui viennent d'arriver au Québec en même temps que renforcer la particularité linguistique et culturelle de la province. Tout en se basant sur la théorie socio culturelle de l'apprentissage des langues, cette étude explore les différentes façons offertes aux professeurs qui encouragent la mise en place d'un environnement d'apprentissage inclusif en classe d'accueil.
\end{abstract}

In 1977, legislation rendered French the official language of Quebec in all public spaces and in business. With the Charter of the French Language (Bill 101), French thus became the language of public schooling for all, with a legal exception made to retain a small English public system for English-speaking children already enrolled in the system and henceforth, for those whose parents had been schooled in English elsewhere in Canada. Following this legislation, new immigrant students were required to attend French-medium schools. To accommodate this influx of learners into the French schools, most of whom spoke neither French nor English at home, a system of reception classes called classes d'accueil- literally welcome classes- was established. The 
implementation of this system was supported by a belief that if newcomers to Quebec learned French, they could then easily integrate into Quebec's society (Gouvernement du Québec, 2001). Since French was then seen as a language atrisk, this was one measure adopted in order to increase the French-speaking ('Francophone') population and to reinforce the position and status of the French language in Quebec and in North America generally.

This article stems from an on-going study of the 'environment' of Montreal's elementary level classes d'accueil, including teachers' language use and other classroom practices. We suggest that there are at least two tensions that play out in the classes d'accueil. On the one hand teachers may see their roles in the classroom in traditional terms, by simply attending to the learning needs of children, albeit via French. On the other hand they may see themselves as agents of social change, whose mandate is to produce new Quebecers who speak French and who will integrate into the Quebec culture. A second but not unrelated tension is seen between Quebec's intercultural policy that strives to be democratic and welcoming of newcomers, while at the same time the impetus is to protect Quebec's unique status as a nation ${ }^{1}$ and revitalize the French language and culture (Allen, 2007). In light of these potentially opposing tensions, this study asks: how do teachers foster an inclusive learning environment in the classe d'accueil? The particular socio-political context of Quebec makes an interesting site for exploring the manner in which the ethos, interactions and activities within the classe d'accueil reflect the social and political interests and other concerns of the larger society (Bourdieu \& Passeron, 1977).

\section{BACKGROUND AND CONTEXT}

Historically, up until the mid 1960s, education for the French-speaking population $^{2}$ in Quebec was in the hands of the Roman Catholic Church. A separate 'Protestant' school system served the English-speaking ('Anglophone') population as well as 'others'- immigrant children and those of the Jewish faith. Only thirteen percent of the Francophone youth, still mostly rural, finished grade 11, against thirty-six percent of the largely urban Anglophone population (Corbo, 2000).

What came to be known as the Quiet Revolution was begun by a small group of Université de Montréal intellectuals, including Canada's former Prime

\footnotetext{
${ }^{1}$ The English word 'nation' refers to an officially recognized political entity. The word nation in French refers more explicitly to a society of people with common roots and shared identity.

${ }^{2}$ Québécois de souche refers colloquially to descendants of the original French-speakers who settled in Quebec in the $17^{\text {th }}$ century.
} 
Minister, Pierre Elliot Trudeau. Their publication in Cité Libre marked the beginnings of liberating French-speaking Quebecers from control of the Church (Magnuson, 1980). Thus began rigorous efforts aimed at revitalizing the social, economic, and political status of the French language and Quebec culture. The establishment in 1964 of a secular Ministère de l'éducation, officially severed education from the church; however separate Catholic and Protestant school systems persisted until 1998 when they became divided along linguistic lines with the school boards being re-named English or French. The aim of the Quiet Revolution became that of modernizing the education system while reinforcing the role of the French language in all aspects of the society, with power slowly shifting from the Anglophone numerical minority (but sociological majority) to the much larger Francophone majority. As the role of the Roman Catholic Church declined and the importance of education increased, the birth rate in the French-speaking population declined drastically (Corbo, 2000).

Prior to the $1960 \mathrm{~s}$, the majority of immigrants settling in Quebec were denied entry into the French Catholic schools, and thus sent their children to English (Protestant) schools. That is, most newcomers to Quebec not only settled in Montreal but also integrated into the English-speaking community, thus further increasing the presence of English in Quebec. Today, immigration to the province is increasing at a faster pace than in any other province in Canada (Statistics Canada, 2006). In 2006, immigrants to Quebec accounted for $11.5 \%$ of the total population, $86.9 \%$ of who chose to reside in Montreal (Statistics Canada, 2006).

As Sarkar (2005) writes, the influx of 'Allophones' (neither English nor French-speaking) into the English sphere coupled with declining birth rates meant that "... it became obvious in the mid-1960s that the only possible way to prevent the decline and eventual disappearance of French in Quebec was to create French-speakers using newly arrived immigrants as raw material" (p. 313). With the passage of Bill 101 in 1977, almost overnight a significant number of immigrants who did not have a functional knowledge of French began attending French-medium schools alongside Québécois learners. The solution to this situation was to implement a system of classes d'accueil. This model consists of preparatory full-time classes of reduced teacher/student ratio for newly arrived immigrant children who do not speak French and who have resided in Quebec for less than five years (McAndrew, 2003). Immigrant children whose families have lived in Quebec for more than five years were not, and are still not today, eligible to attend classes d'accueil, even though many do not yet speak French when they 
begin school. This has created a situation in which many children are placed in other types of special classes because of their difficulties learning in French. ${ }^{3}$

\section{THE CLASSE D'ACCUEIL MODEL}

The classe d'accueil model, still in place today and unique in North America, has a dual purpose. First, it aims to teach 'limited French proficient' immigrant students functional French so that they can be transferred to regular classes; ideally this takes one year although it sometimes takes two or even three years. Second, the classe d'accueil is mandated by Quebec's official curriculum to integrate immigrant children into Quebec's Francophone culture ${ }^{4}$ (Gouvernement du Québec, 2001). As Allen (2007) posits, "through school policies, programs, and practices as well as laws about the use of French in the wider community of Quebec, new-immigrant youth are strongly encouraged to take up a new identity, one which adopts French as the common language, and to participate in Quebec's distinct society through that language" (p. 167). This is explicitly stated in Quebec's Policy Statement on Educational Integration and Intercultural Education (1998a), which reads as follows:

In addition to ensuring that immigrants learn French, we must encourage them to take pleasure in using it in everyday life, which will enable them to better understand the French character of Quebec society, and its history, and to develop a sense of belonging and a commitment to the survival of French" (emphasis ours, Gouvernement du Québec, p. 30).

Because the classe d'accueil model was implemented abruptly, teachers were provided very little in-service professional development and thus faced new challenges in their teaching. As Sarkar (2005) explains, "the training of many welcome class teachers hired in the 1980s or 1990s consisted of a brief series of workshops delivered over a weekend or during one or two professional development days" (p. 315). Today, professional training for classe d'accueil teachers is embedded in Bachelor of Education French-as-a-second-language programs found in several Quebec Universities. However, due to increasing enrollment in classes d'accueil, especially in inner-city schools, many teachers currently teaching these classes do not possess the educational background or formal qualifications to teach French as a second or additional language.

\footnotetext{
${ }^{3}$ This raises another matter that will be addressed in a later article.

${ }^{4}$ Rarely is "the Quebec culture" actually defined in the literature reviewed for this article. It refers to the French-speaking inhabitants' collective identity as it is defined alongside of, and in the face of, a primarily Anglophone Canada.
} 


\section{THE CULTURAL POLITICS OF QUEBEC'S LANGUAGE DEBATE IN THE CLASSROOM- THEORETICAL CONSIDERATIONS}

In the last 30 years, efforts to revive the status of the French language were fairly successful, as evidenced by the fact that a large portion of immigrants now use French in their everyday lives (Pagé \& Lamarre, 2010; Salvatore, 2001). Nevertheless, attitudes in Quebec remain divided. The long-standing prevalence of English in the province coupled with a steady influx of immigrants has meant that for some, Quebec's distinct culture and language remain at risk of becoming extinct (La Haye, 2010; Steinbach, 2010). In fact, McAndrew (2010) claims that Quebec is a 'fragile linguistic majority' within a primarily Anglophone Canada. There thus seems to be an enduring need to safeguard the French language and culture in Quebec. As the study being reported here shows, it appears that this sentiment is well internalized by some classe d'accueil teachers.

Several scholars have noted that one's first language is almost always associated with personal identity, loyalty to family, and membership in a community (Cummins, 2003; Lamarre, 2003). This is true in Quebec, where the long-enduring language debate has meant that French is not only seen as a linguistic resource, but is also tied to a strong sense of nationality. Heller (1999) explains that when the legitimacy and authenticity of a minority group, such as the French in Canada, has historically been challenged by a dominant group-- the English in Canada--that minority may be inclined to strengthen its ties to ideological, material and symbolic resources associated with its community. This is especially true for old stock Quebecers (de souche), those who most closely identify with Quebec's distinct language and culture. Quebec's state-supported identity also represents a common cultural heritage and way of life, and is articulated through language choice and use in everyday activities. In other words, the act of speaking French in Quebec (as opposed to English or any other language) can be seen as an exertion of ethno-cultural power.

The aforementioned dynamics of language and power in Quebec have important implications in the education sector for French Québécois teachers who may be personally and academically invested in the promotion and protection of the French language, but who must also embrace diversity and welcome immigrant children in their classrooms. How do teachers negotiate these two competing discourses? Since a major component of dominant discourse in Quebec revolves around ensuring that immigrant children do not assimilate into the Anglophone (English-speaking) sector, in this research we are particularly interested in exploring how classes d'accueil teachers facilitate the learning of a new language and integration into the host society without loss of the learner's home language and disruption to the learner's sense of identity. 
In order to cast theoretical light on this complex socio-cultural situation, we turn to sociocultural theories of language learning (Norton, 2006, inspired by Bakhtin, 1981, 1984; Bourdieu, 1977, 1984; Weedon, 1987; Lave and Wenger, 1991) which focus on the relationship between language, identity and the wider social and cultural world. Sociocultural theorists reject at the outset that learning a language is "an individual process of internalizing a neutral set of rules, structures, and vocabulary of a standard language" (Norton, 2006, p.5), viewing identity formation as a complex, negotiated and at times contradictory process that is framed within power relations embedded in larger institutional and community practices. As Pavlenko and Blackledge (2004) state: "In multilingual settings, language choice and attitudes are inseparable from political arrangements, relations of power, language ideologies, and interlocutors' views of their own and others' identities" (p.1). Therefore in multilingual contexts, certain identities- those that are most ideologically close to the dominant group's, are legitimized and valued more than others. This has important implications for immigrant learners in Quebec who, as part of their integration process, must adopt a new 'state-supported identity' that is commensurate with Quebec's national 'commitment to the survival of the French language'.

The process of integrating into a society is conceptualized as potentially additive in nature, resulting in a gain of a new language and culture. This may occur especially when the home language and culture of the immigrant child is well supported by both the school and the family and is in line with Quebec's Policy Statement on Educational Integration and Intercultural Education (1998), which reads as follows: "Integration may be defined as a long-term multidimensional adaptation process, which is distinct from assimilation, the overall adoption of the host society's culture and fusion with the majority group" (p. 8). In contrast, the process of assimilation is seen as potentially subtractive because it may result in replacement of the home language and culture with that of the host society. When this occurs, the learner's identity tends to be disrupted as well, with serious consequences for continued success in school (Cummins et al., 2005).

\section{LEARNING THE LANGUAGE OF SCHOOLING: SOME IMPLICATIONS FOR PERSONAL IDENTITY}

Wong-Filmore's 1991 study entitled "When learning a new language means losing the first", was one of the first to highlight the pedagogical consequences of assimilation. In this work, Wong-Filmore surveyed immigrant and Native American youth in the United States who were learning a second language and found that additional language acquisition often results in loss of the home 
language, depending on the timing and conditions under which the target language is learned. Such language loss has costly consequences, especially when the parents only speak the home language; communication within the family is disrupted. Wong-Filmore also stressed the importance for children who are learning an additional language to interact with native-born peers. Since the classes d'accueil are composed solely of immigrant students who learn together as a sheltered closed group apart from regular education classes, access to French-speaking peers may be quite limited and restricted to recess and the lunch hour.

The tensions referred to at the beginning of this article are evident in Steinbach's (2010) study of adolescent youth's views on integration in a semirural region of Quebec. The immigrant high school students in her study revealed that they did not always feel welcome by their classmates and teachers. The French-speaking students saw their own cultural identity as threatened if the new students did not conform to Quebec's societal norms. Such tensions may also be found in elementary-level classrooms in Montreal where over $75 \%$ of newcomers to Quebec settle.

Sarkar (2005) conducted a five-year longitudinal study in a kindergarten classe d'accueil, during which she examined how the teacher structured classroom interaction to promote French-as-a-second-language. In line with Steinbach's aforementioned findings, she writes: "The French school system mandate of making sure all children become fluent users of French often translates into a rigid intolerance for languages other than French on the part of many teachers" (p.325). Thus, the use of other languages, and particularly of English, may develop into a symbol of resistance. Unlike other teachers that Sarkar had previously observed, the teacher in this study was 'exceptional' in that she was open to languages other than French in the classroom. She also encouraged the children to draw from their bilingual repertoires, informed the parents of the benefits of home language maintenance, and occasionally communicated using other languages with her students.

Heller (2001) has reported that in second language classrooms, where the language of instruction is a minority language such as French in Canada, institutional monolingualism often takes place. Institutional monolingualism is described as the enforcement of the language of instruction as the only language to be spoken in the classroom. This often results in the teacher reprimanding students for using other languages, and "spending a fair amount of time exhorting or imploring, in shouts and in whispers, Parlez Français!" (p. 388). As also implied by Sarkar (2005), French as second language teachers in Quebec may 
interpret their mandate as one of protecting and promoting the French language and culture, and thus create monolingual classroom environments.

Allen (2007) has argued that mandatory schooling in French may be the most important way that Quebec has succeeded in ensuring French as "not just the official language but the politically, economically and socially dominant language" (p.167). She conducted a study that reported on the integration processes of four newcomer adolescent youth in Quebec. Given that two contradictory discourses circulate in Quebec, one of protecting the unique cultural and linguistic heritage, and the other of embracing diversity through welcoming immigrants, Allen focused on understanding how the students made sense of themselves in the classe d'accueil context. Her data reveals that in some cases, the French language acted as a barrier to integration into the mainstream. She found that the same opportunities were not available for all students and depended largely on a variety of factors that were out of the students' control (such as linguistic ability, academic ability and prior education). Allen suggests that schools ought to place more emphasis on "learning French through inclusion in school activities and the mainstream community right from the beginning of their experience in Quebec" (p. 175).

Further research in the teaching/learning process in multilingual classrooms supports the notion that culturally and linguistically diverse students come to school with a wealth of already acquired knowledges and experiences, which could be relevant in the new schooling context and used as classroom resources, but which a majority of teachers remain largely unaware of how to incorporate into the classroom (Bayley \& Schecter, 2003; Cummins et al., 2005; Schecter \& Cummins, 2003). In fact, students' home languages and cultures are often neglected if not ignored, which is considered by Wong-Fillmore, Cummins and others to have important implications for the students' personal identities.

Cummins et al. (2005) collaborated with educators teaching in the greater Toronto area, in a school where over 40 different languages were spoken; the research team worked to implement a bilingual classroom activity known as 'dual language identity text'. The children invented stories and translated them into both English- the language of instruction- and their home languages with the help of teachers, parents and community members. Findings from this study show that since the students' prior knowledge is "encoded in their home languages...educators should explicitly teach in a way that fosters transfer of concepts and skills from the student's home language to [the language of instruction]" (p. 38). 


\section{METHODOLOGY}

The present study used qualitative methodology to explore teachers' language attitudes and language use in the classe d'accueil. The main sources of data were in-depth, semi-structured teacher interviews supported with bi-weekly audiorecorded classroom observations and extensive descriptive and reflective field notes. Four 'welcome class' teachers were each interviewed for one hour and a half by the lead author concerning a wide variety of topics such as: how they interpret their mandates as classe d'accueil teachers; their perceptions of diversity and difference; any challenges they face in classes where the learners come from many different language backgrounds; how they structure the learning environments in their classrooms; and their understandings of certain aspects of the official curriculum.

\section{The setting}

Observations took place in one school located in a southwest, working class borough of Montreal, where a large number of immigrants settle. The three classrooms observed were divided according to age groups (6-8 in the youngest, 9-10 in the middle level and 11-12 in the eldest). Most of the students had been attending school for four months when the study began in January 2010, and thus already had made significant progress learning French. Their ethnic and linguistic backgrounds were extremely diverse, and most of them came from non-Western homes. The researcher observed French and math lessons twice a week in each of the classrooms, focusing on the way the teacher interacted linguistically with her students. At first glance, the students seemed to have already adjusted well into their classrooms. Groups of friends had already formed, and all seemed to have a positive relationship with their teachers.

\section{Participants}

Although the majority of classe d'accueil teachers are old stock Québécois ( souche) (Sarkar, 2005), two of the four teachers in this study are originally from outside of Quebec. They both immigrated to Quebec themselves, which as the findings reveal, influenced their teaching philosophy and attitudes toward their students. The four teachers ranged in age from 24 to 50 and had been teaching for one to 15 years. The interviews were conducted in whichever language the participants felt most comfortable. 


\section{T1: Marie-Claude $e^{5}$}

Marie-Claude is a young woman of 24 who grew up in Saguenay, Lac St-Jean. She describes herself as an old stock Quebecer (de souche). She completed her Bachelor of Education at the Université du Québec à Montréal (UQAM) in 2008. In 2009, she taught French as a Second Language for adults, before landing her current post in the winter of 2010. At the time of her interview, she had been teaching in the classe d'accueil setting for six months. She describes herself as very well traveled, having visited many countries such as China, Thailand, Cambodia, Switzerland, France and Germany. French is her first language, though she is fluent in English, has a 'good base' in Spanish and understands some German and Mandarin. Her avid enthusiasm toward language learning has helped to put herself in her students' shoes (pour nous aussi en tant qu'enseignants, il est important de se mettre dans la peau de nos élèves).

\section{T2: Huguette}

Huguette is also an old stock Quebecer (de souche). She was born in Quebec and also obtained her bachelor's degree in French as a second language from UQAM. She has been teaching classes d'accueil for the last thirteen years. Previous to this, she taught French immersion to English-speaking students in an alternative school. She has experience teaching abroad in Venezuela and has traveled to South America, South East Asia and Europe. Huguette is perfectly fluent in standard Québécois French, her first language, English, and Spanish. Her fiancé is Mexican, and she communicates in Spanish at home.

\section{T3: Fatima}

Fatima was born in Ontario to a Spanish Catalan mother and Bangladeshi father, although she does not speak either language fluently. She grew up speaking English and learned French at the age of 18, when she spent a year abroad as an 'au pair' in France. She majored in French literature in University and obtained her teaching French as a second language qualifications from the University of Ottawa Teachers' College. She married a Québécois and moved to Montreal shortly after. Fatima has been teaching in the classe d'accueil setting for twelve years. She is fluent in French (although still has a slight accent), English and speaks a little Spanish. She communicates in both French and English at home.

\footnotetext{
${ }^{5}$ Only pseudonyms are used.
} 


\section{T4: Kamilah}

Kamilah was born in Dakar, Egypt. Her family immigrated to Montreal when she was 15 years old. She describes her own immigration process as extremely difficult. She had trouble making friends as her family immigrated at the end of the school year in May. Kamilah felt that her teacher and peers made no effort to help her integrate into the new society. She reports having experienced acts of discrimination. Kamilah grew up speaking both Arabic and French, and later learned English and Italian. She possesses a Bachelor of Education and a Master's degree in educational psychology. Although her bachelor degree does not officially qualify her to teach French as a second language, Kamilah feels that her own immigration experience greatly informs her teaching practice, especially when it comes to the integration of newcomers. She has been teaching for fifteen years, three of which were spent teaching classes d'accueil. At the time of the interview, Kamilah was teaching a split grade 3/4 class. She was interviewed because of her unique position as an immigrant herself and her extensive experience in the classe d'accueil setting.

\section{FINDINGS}

The data were coded and scrutinized for repeated themes. Through an in-depth analysis of the interviews, audio-recordings and field notes, four key themes emerged. Each is discussed in detail below.

1. Teacher's views of their roles

2. Home language maintenance and language use in the classroom

3. Conceptualizing 'French proficiency' as marker of social status: The 'ticket' to classroom participation

4. Understanding the curriculum

\section{Teachers' Views of Their Roles}

The participants understood their roles as classe d'accueil teachers very differently. Teachers Marie-Claude and Huguette (T1 and T2) were most invested in promoting the French language in the classroom. They see themselves as "ambassadors of Quebec in charge of transmitting knowledge about its language and culture" so as to ensure that it lives on through future generations. Huguette expressed her worries about the French language and culture being at risk of becoming extinct in the following comment:

La question qui est très, très For me, the question that is very, very importante pour moi, c'est qu'on garde important is that we preserve French. 
le français. C'est une richesse. Si on décide de devenir juste des Anglophones ici, on va avoir perdu quelque chose, on va avoir perdu une langue, et la langue va avec une culture aussi...

Additionally, Marie-Claude expressed a need to stay updated with various cultural events taking place in the society. Marie-Claude feels as though she embodies the "Olympic torch of Quebec's language and culture" (On est comme le flambeau de la langue et de la culture), explaining that it is important to have a clear idea of what constitutes la Francophonie.

In contrast, Fatima and Kamilah (T3 and T4) saw their roles as facilitator, social worker and guide in charge of helping their students navigate a new world. As stated above, Kamilah expressed that having gone through what the students in her class are living greatly informs her teaching practice. Although she agrees that it is important to promote French, she is less invested in this mission than the two Québécoise teachers (Marie-Claude and Huguette), and even reported that in some cases, newly arrived immigrant children ought to be able to go to school in English.

Je ne suis pas tout à fait d'accord [avec le fait que tous les immigrants doivent aller à l'école en français au Québec]. Par principe, oui... Pour respecter la langue d'ici, et pour la préserver, ça c'est bien important. Sauf que quand on arrive à des cas d'exception où l'élève est vraiment en difficulté, ...Et qu'on insiste, qu'on insiste pour qu'il apprenne tout en français, et qu'en bout de ligne après deux ans d'accueil, il n'y arrive toujours pas, je pense que c'est important qu'on lâche prise et qu'il aille en anglais.
I don't completely agree with [the fact that all immigrants to Quebec have to go to school in French]. In principle, yes, to respect the language, to preserve it, it's quite important. Except that in special cases, where the student is experiencing academic difficulties....and we insist and insist for him to learn everything in French, and that after two years in accueil, he still can't pass, then I think it's important that we let go and that he goes to school in English.

Unlike Marie-Claude and Huguette who prioritized the role of the classe d'accueil as a means to ensure a future for Quebec's national identity, Kamilah considers the interests of the children, in this case of those experiencing academic difficulty in French classes, as a priority. Such different interpretations 
of what constitutes the role of the classe d'accueil teacher reveal the extent to which teaching is subjective and tied to personal, ethnic, and political identity. As Cummins (2000) explains, "what educators bring into the classroom reflects their awareness of and orientation to issues of equity and power in the wider society..." (p. 6).

\section{Home Language Maintenance and Language Use in the Classroom}

As indicated earlier, all four teachers viewed multilingualism as an asset (la langue est une richesse, $T 1$ ) and spoke about the importance of maintaining the home language.

T3: I think it's very important for kids and their families to keep their cultures and to keep their languages alive.

T4: La langue maternelle fait partie de nos racines. Tu prends un arbre, tu le déracines, tu le plante ailleurs. Les racines vont tenir peut- être un peu, mais jamais comme à l'endroit où il est né. C'est très important la langue maternelle. Elle est riche de l'expérience de vie, de souvenir d'enfance, c'est toute une culture.
T4: Our mother tongue is a part of our roots. If you take a tree, uproot it and plant it elsewhere, the roots will maybe hold, but never like where it was born. [One's] mother tongue is very important. It is rich with life experience, childhood memories...it's an entire culture.

Perhaps surprisingly considering the consensus amongst the teachers that children should not lose their home languages, the classe d'accueil was not a space where other languages could be spoken. In fact, these teachers generally did not allow students to communicate in languages other than French. Speaking other languages ranged from being lightly discouraged to being a serious infraction of the rules. The rationale offered for insisting on French-only in the classroom was the belief that a second language would never be learned unless the students were submerged in it. Two teachers reported that their university training emphasized that it is important to "never speak anything other than the target language " (ne jamais parler d'autres langues que le français, T2) in second language classroom. With this line of thought, when other languages are permitted in the classroom, children "become lazy" (ils ne se forceront pas, T2), rely on translation in their home languages and will never learn French. These attitudes are in contradiction to what researchers in the field have posited. For example, Cummins (2007) explains that learning a second language independently from other languages and without reference to home language is 
"largely unsupported by empirical evidence and inconsistent with current understandings both of how people learn (Bransford, Brown \& Cocking, 2000 as cited by Cummins, 2007) and the functioning of the bilingual and multilingual mind" (p. 222).

The teachers also implied that allowing other languages in their classrooms would force them to deviate from their 'mandates as classe d'accueil' teachers, which is to promote the French language.

T4: ...Ils peuvent s'exprimer dans leur propre langue chez eux. Ils sont ici pour apprendre le français. Donc, s'ils sont ici pour apprendre le français, et qu'ils commencent à $s$ 'exprimer dans leurs langues, on va à l'encontre de l'objectif, 'se familiariser avec son milieu', de s'intégrer, d'apprendre à connaître la culture du Québec. On va à l'encontre de tous ces objectifs-là.

T1: En tant que professeur, nous on voudrait qu'il parle français dans la classe, c'est important, ça fait partie du mandat des classes d'accueil.
T4: ...They can speak their own languages at home. They are here to learn French. So, if they are here to learn French, and they start speaking their home languages, we're going against the stated objectives "se familiariser avec son milieu', to integrate, learn to know the culture of Quebec. We're going against all of those objectives. (Emphasis ours)

T1: As teachers, we would like for them to speak French in class, it's important, it's part of the 'welcome class' mandate.

The above quotes corroborate Sarkar's (2005) view that interpretation of the mandate set forth by the French school board's official curriculum translates into 'a rigid intolerance for other languages'. Under this line of thought, the second language classroom should have very little to do with the students' first languages. French as a second language must be learned as an autonomous system and with no reference to the students' home languages. 


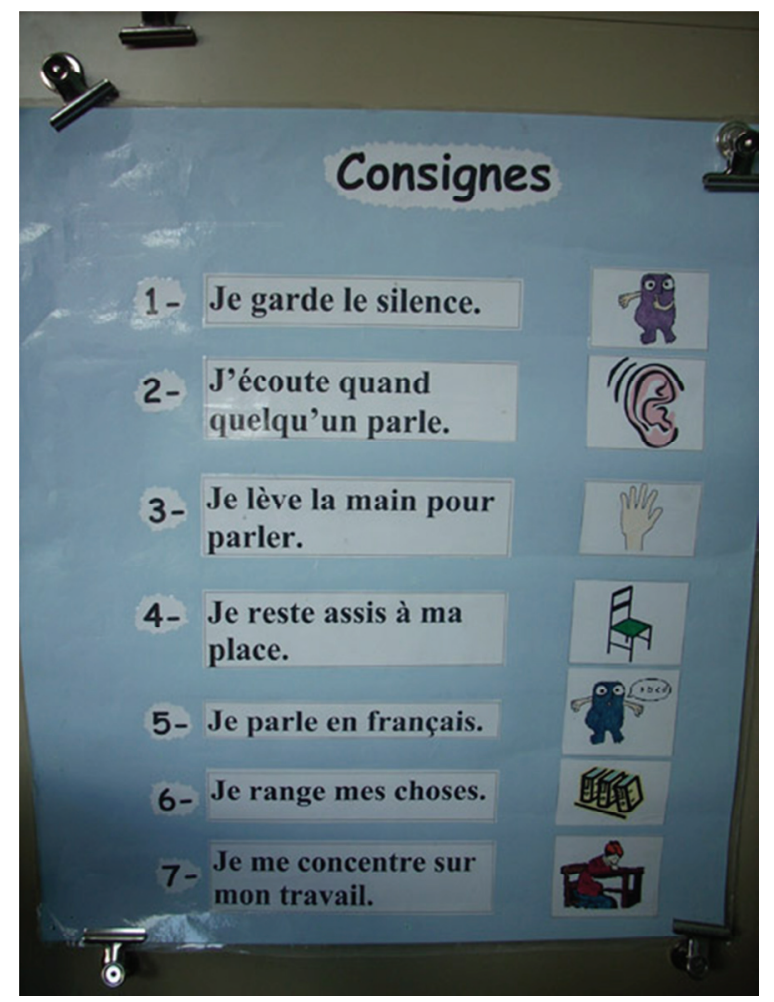

Two of the teachers had classroom management systems controlling the use of other languages in class. Marie-Claude recorded on the top right corner of the chalkboard the number of times she heard the students speaking other languages in the classroom. If after a week, the number rose higher than ten, the students would lose their Friday afternoon play period (période de récompense). Similarly, Huguette jotted down daily the names of the individual students who spoke other languages. At the end of each day, those who broke the rule were assigned extra homework. The students would have to copy "je dois parler en français à l'école "

multiple times, depending on how often they slipped up.

All four teachers had the same rule chart posted on a wall in their classrooms (see left). Along with rules that ensure respect and responsibility such as 'I raise my hand to speak' (Je lève la main pour parler) and 'I listen when someone else is speaking' ( $J$ 'écoute quand quelqu'un parle), was written 'I speak in French' (Je parle en français).

Conceptualizing' French Proficiency' as a Marker of Social Status: The 'Ticket' to Classroom Participation

Participation in classroom activities was dependent on French proficiency in all classrooms observed. Students who had not yet acquired the ability to speak in French were silenced, excluded and given solitary 'busy work' (such as work in a calligraphy notebook). The teachers did not seem to believe that children could contribute to the classroom without the use of French. The teachers who most 
closely identified with Quebec nationalism (T1 and T2) organized classroom language activities in ways that gave French the highest linguistic status. For instance, Huguette (T2) warned her students that if they continued to speak other languages in the classroom, "they would never finish the year and would not be able to move up to regular classes" (on n'arrivera pas à finir l'année et vous ne pourrez pas aller en classe régulière).

Since the understood aims of the classe d'accueil are to prepare for mainstream classes, the process of learning French became a means to an end. Because the French language was ascribed the highest status, the classe d'accueil became a temporary subordinate space that all immigrant children must pass through in order to reach the end goal of transitioning into the regular stream. Immigrant students were thus disempowered and stigmatized within the culture of the school as a whole, much as the English stream in a French immersion school was looked down upon as far back as the early 1980s (Cleghorn \& Genesee, 1984). During the three months of observation, the lead author did not once witness the teachers explicitly acknowledging, and much less drawing from the students' linguistic and cultural backgrounds. Instead of valuing their lived experiences and helping students feel proud of that they already knew, teachers seemed to only praise students for using the language of instruction in the classroom. In line with Allen (2007) and Steinbach's (2010) findings, acquiring the ability to speak French was treated as a resource that ought to be mastered before the integration process could begin.

\section{Understandings of the Curriculum}

The Quebec Education Program (QEP) outlines two competencies for students placed in classes d'accueil at the elementary school level. Students must learn 'to communicate in French' (Interagir en Français) and learn 'to adapt to Quebec's culture' (Se familiariser à la culture de son milieu) (Gouvernement du Québec, p. 111, 2001). In other words, teachers must assess and evaluate their newcomer students based on how well they have acquired the ability to communicate in French and how well they appear to be integrating into Quebec society.

The four teacher-participants made sense of this second competency in different ways, with interpretations ranging from "learning the rules of the school" (Apprendre les règles de l'école, T4), 'learning about Quebec's history' (Apprendre l'histoire du Québec, T2), to "participating in major holidays celebrated by the school and greater society" (T3). They admitted to receiving little professional guidance and support, and expressed great confusion about how to 'teach' competency number two. The teachers had trouble understanding 
what was intended by 'adapting to the Quebec culture' and what characteristic in the learner would be indicative of such an adaptation.

T2: Peut-être que je me trompe. Je me T2: Maybe I'm wrong. I've always suis toujours posé la question et ça n'a jamais été clair, peut-être que je suis dans le champ. C'est vraiment pas facile à évaluer, et on n'a pas de balise. Personne ne nous dit comment évaluer ça... asked myself that question, and it's never been clear, maybe I'm completely off. It's really not easy to assess, and we have no markers. Nobody's told us how to evaluate that.

Fatima's (T3) comments reflect her uncertainty with what exactly constitutes the Quebec culture, and which aspects of it are 'teachable' and most important for both the host society and its newcomers.

T3: Qu'est-ce qui est important? Qu'est-ce qu'il faut leur donner? ...Qu'est-ce qu'on leur montre qui touche vraiment la culture? Est-ce que c'est la cabane à sucre? Est-ce que c'est les fêtes...La Saint-Jean, est-ce que c'est important? La fête de la reine? C'est quoi exactement 'la culture'? Quels sont les éléments de base pour atteindre l'objectif, de 'se familiariser'. Ce n'est pas clair. C'est vraiment laisser à l'enseignante. Et là on commence à se perdre là-dedans...

T3: What's important? What do we have to give them? What should we show them that actually relates to culture? Is it the sugar shack? Is it the major holidays? La Saint-Jean [Baptiste]? Is it important? What about the Queen's birthday? What exactly constitutes 'culture'? What elements need to be taught in order to meet the stated objective 'de se familiariser'? It isn't clear. It is left up to the teacher. And we get lost in it.

Kamilah (T4) spoke about the fact that integration is a personal process that is undertaken differently by each individual. She expressed confusion and discomfort with being cast in a position of authority, as a teacher who must provide a grade for something that she does not believe she can accurately assess.

T4: It's hard to evaluate, it's very personal. And you know, it's a personality thing too, like I have some kids that are just shy. Am I not going to give them a good mark because of that? Or maybe they don't have good memories about where they came from.

Like Laura, she has an awful background, and at the beginning, she just wasn't ready to talk about anything, and she'd get angry about it. So am 
I to give her a bad mark because she's been traumatized and she's not ready to talk about it? Who am I to judge?

Later Fatima continued:

...Personally, I don't think kids should be graded based on this competency. It's probably in place because I think it looks good to say that in school when the immigrants come we try to put them in a situation where they have no choice but to be a certain way. It's probably very political. But I'm not going to keep a kid back because that competency is not passed.

\section{DISCUSSION}

Classes d'accueil Teachers' uncertainty of how to facilitate integration all the whilst respecting and promoting the French language and Quebec culture results in the structuring of classroom practices that may at times exclude and alienate newcomer students. Since its inception in 1977, the system of classes d'accueil has been used in part to advance the interests of the greater society, that of increasing the status of French in the Quebec province and ensuring that future Quebecers do not gravitate to the English-speaking sector of the society. As the findings of this study suggest, whenever students spoke languages other than French in the classroom, their language choice was perceived negatively by the teachers, possibly as a form of resistance towards the 'commitment' to the French language that students were to take up during their time in the classe d'accueil. Additionally, by including 'I speak French' to the written class rules (les consignes) little place was left in the classroom for intercultural values, as stated in the Policy Statement on Educational Integration and Intercultural Education (1998a). Enforcing communication in the target language as a form of discipline is not likely to have the same impact on students' motivation as would encouraging its use in everyday life. Lastly, although all teachers in this study could speak other languages, they almost exclusively spoke French in the classroom. Using other languages would have deviated from their mandates, which they understood as that of promoting French, the language closely associated with Quebec nationalist interests.

\section{CONCLUSION}

The paradoxical nature of Quebec as a province that aims to be democratic, pluralistic and welcoming to immigrants, while concurrently working to protect 
its seemingly fragile linguistic and political identity has important implications for the teaching of newcomer children. For one, it renders the role of classe d'accueil teachers as potentially conflicted and confusing. Secondly, it may contribute to the structuring of classroom language environments that reproduce unequal power relations in Quebec's society. Popular Quebec nationalist discourses of promoting the French language and increasing Quebec's sociopolitical status were transmitted--consciously or not--by the teachers in this study. Moreover, ascribing social status to French and enforcing it as the only language to be spoken in the classroom may serve to marginalize the immigrant students that Quebec supposedly welcomes. Since most teachers enforced the French-only rule, students with limited French proficiency- that is virtually all students enrolled in classes d'accueil- were excluded from classroom participation at one time or another. Under this type of linguistic regime, the integration process does not begin when the children first enter the classroom, but only once they have mastered French well enough to express themselves. Lastly, teachers varied widely in their interpretations of their mandate and expressed confusion deciphering the official curriculum. Implications are for policy makers to redefine the stated competencies so the Quebec Education Program for classes d'accueil is clearer for teachers to follow. It also ought to take into account recent well-founded research on second language learning.

In the opening remarks of the Policy Statement For Educational Integration and Intercultural Education (1998), it is clearly stated that public education in Quebec is to have zero exclusion (p.3). The evidence from this small study suggests that at least in some classrooms a number of the learners are being actively excluded from the learning process. If this is occurring more widely, then it is imperative that we further explore how teachers structure the learning environment in Quebec's classes d'accueil so that the learners' needs are fully supported. The findings of this study may suggest that inclusive education in Quebec, especially with respect to the schooling of newly arrived immigrants, is not always the case.

\section{References}

Allen, D. (2007). Just who do you think I am? The name-calling and name-claiming of newcomer youth. Canadian Journal of Applied Linguistics, 10(2), 165-175.

Bakhtin, M. (1981). The dialogic imagination: Four essays by M.M. Bakhtin. Austin, TX: University of Texas Press.

Bakhtin, M. (1984). Problems of Dostoevsky's poetics (C. Emerson, Trans.). Minneapolis, MN: University of Minnesota Press.

Bayley, R. \& Schecter, S. (Eds.). (2003). Language socialization in bilingual and multilingual societies. Toronto, ON: Multilingual Matters.

Bourdieu, P. (1977). The economics of linguistic exchanges. Social Science Information, 16(6), 645-668.

Bourdieu, P. (1984). Distinction: A social critique of the judgment of taste. (R. Nice, Trans.). London: Routledge. 
Bourdieu, P. \& Passeron, J.C. (1977). Reproduction in education: Society and culture. California: Sage.

Bransford, J., Brown, A. \& Cocking, R., (Eds.). (2000). How people learn: Brain, mind, experience, and school: Expanded edition. Washington, DC: National Academy Press.

Cleghorn, A. \& Genesee, F. (1984). Languages in contact: An ethnographic study of teacher interaction in an immersion school. TESOL Quarterly, 18(4), 595-625.

Corbo, C. (2000). Repenser L'école: Une anthologie des débats sur l'éducation au Québec de 1945 au rapport parent. Montréal, QC: Les Presses de l'Université de Montréal.

Cummins, J. (2000). Language, power and pedagogy: Bilingual children in the crossfire. Toronto, ON: Multilingual Matters.

Cummins, J. (2003). Challenging the construction of difference as deficit: Where are identity, intellect, imagination, and power in the new regime of truth? In P. Trifonas (Ed.), Pedagogies of difference: Rethinking education for social change, (pp. 41-60). London: Routledge.

Cummins, J. (2007). Rethinking monolingual instructional strategies in multilingual classrooms. Canadian Journal of Applied Linguistics, 10(2), 221-240.

Cummins, J., Bismilla, V., Chow, P., Cohen, S., Giampapa, F., Leoni, L., ... Sastri, P. (2005). Affirming identity in multilingual classrooms. Educational Leadership, 63(1), 38-43.

Heller, M. (1999). Linguistic minorities and modernity. New York, NY: Longman.

Heller, M. (2001). Legitimate language in a multilingual school. In M. Heller \& M. Martin-Jones (Eds.). Voices of authority: Education and linguistic difference. (pp. 381-402) Westport, CT: Ablex publishing.

Gouvernement du Québec. (1998). A school for the future. Policy statement on educational integration and intercultural education. Ministère de l'éducation, des loisirs et des sports. Retrieved from: http://www.meq.gouv.qc.ca/REFORME/int_scol/Bro_a.pdf

Gouvernement du Québec. (2001). Programme de formation de l'école Québécoise:Education préscolaire et enseignement primaire.Chapitre 5.3- Accueil. Ministère de l'éducation, des loisirs et des sports. Retrieved from : http://www.mels.gouv.qc.ca/dgfj/dp/programme_de_formation/primaire/prform2001h.ht ml.

La Haye, D. (2010, May 8). Landry : Need for Quebec sovereignty 'urgent'. The Toronto Sun. Retrieved from: http://www.torontosun.com/news/canada/2010/05/08/13880156.html

Lamarre, P. (2003). Growing up trilingual in Montreal. In R. Bayley \& S. Schecter (Eds.), Language socialization in bilingual and multilingual societies. (pp. 62-82) Toronto, ON: Multilingual Matters.

Lave, J. \& Wenger, E. (1991). Situated learning: Legitimate peripheral participation. Cambridge: Cambridge University Press.

McAndrew, M. (2001). Immigration et diversité à l'école: le débat Québécois dans une perspective omparative. Montréal, QC: La Presse de l'Université de Montréal.

McAndrew, M. (2010). Les majorités fragiles et l'éducation. Montreal, QC: Les Presses de l'Université de Montréal.

Magnuson, R. (1980). A brief history of Quebec education. From New France to Parti Québécois. Montreal, QC: Harvest House.

Norton, B. (2006). Identity as a sociocultural construct in second language education. In K. Cadman \& K. O'Regan (Eds.) TESOL in context [special issue], 22-33.

Pagé, M. \& Lamarre, P. (2010). L'intégration linguistique des immigrants au Québec. Institute for Research on Public Policy, report no. 3. Quebec Metropolis Centre: Immigration and Metropolis. Retrieved from: http://im.metropolis.net/frameset_e.html

Pavlenko, A. \& Blackledge, A. (Eds.). (2004). Negotiation of identities in multilingual contexts. Toronto, ON: Multilingual Matters.

Sarkar, M. (2005). A l'école on parle français: Second language acquisition and the creation of a community in a multiethnic Montreal kindergarten. In F. Salili \& R. Hoosain, (Eds.) Language in multicultural education. (pp. 310-342). Greenwich, CT: Information Age Publishing.

Schecter, S. \& Cummins, J. (Eds.). (2003). Multilingual education in practice: Using diversity as a resource. Portsmouth, NH: Heinemann.

Steinbach, M. (2010). Quand je sors d'accueil: Linguistic integration of immigrant adolescents in Quebec secondary schools. Language, Culture \& Curriculum, 23(2), 95-107.

Statistics Canada. (2006). Immigration in Canada: A portrait of the foreign-born population in 2006 census: 
Immigrants in the provinces and territories. Quebec: Highest proportion of foreign-born population ever. Retrieved from: http://www12.statcan.ca/census-recensement/2006/as-sa/97-557/p10-eng.cfm Salvatore, F. (2001). Vive a trilingual Quebec! The UNESCO Courier, July/August, 64-66. Retrieved from: http://www.unesco.org/courier/2001_07/uk/education.htm

Weedon, C. (1987). Feminist practice and poststructuralist theory. London: Blackwell.

Wong Fillmore, L. (1991). When learning a second language means losing the first. Early Childhood Research Quarterly, 6(3), 323-346.

Gabrielle LBreton-Carbonneau (g_breton@education.concordia.ca) is a graduate student in the Educational Studies Program offered through the Dept. of Education at Concordia University. Her research interests include second language education, minority language education, multilingualism and educational sociolinguistics.

Ailie Cleghorn (ailie@education.concordia.ca) is a Professor of Education at Concordia where she teaches graduate courses on Literacy and Development and Research Methods in Education as well as an undergraduate course on Comparative Education. 